\title{
Sprawozdanie
}

\section{Seminarium nt.: Modele sądowej kontroli konstytucyjności prawa, Olsztyn, dnia 14 października 2011 r.}

Dnia 14 października 2011 r. na Wydziale Prawa i Administracji Uniwersytetu Warmińsko-Mazurskiego odbyło się seminarium naukowe poświęcone Modelom sądowej kontroli konstytucyjności prawa. Seminarium zostało zorganizowane przez Katedrę Prawa Konstytucyjnego, a udział w nim wzięli, obok pracowników Katedry, przedstawiciele: Uniwersytetu Gdańskiego, Uniwersytetu Kardynała Stefana Wyszyńskiego, Instytutu Nauk Prawnych Polskiej Akademii Nauk oraz Kancelarii Sejmu.

Seminarium otworzył dziekan WPiA prof. dr hab. Bronisław Sitek. Powitał on bardzo serdecznie prelegentów, zaproszonych gości, pracowników Wydziału oraz licznie zgromadzonych studentów. Dziekan podkreślił znaczenie zorganizowanego przedsięwzięcia dla rozwoju nauki polskiej, wskazując, iż tematyka seminarium może skłonić do poszukiwania nowych rozwiązań i modeli funkcjonowania sądownictwa konstytucyjnego w Polsce.

Przewodnictwo pierwszej sesji objęła dr Małgorzata Augustyniak (Uniwersytet Warmińsko-Mazurski). Sesja ta poświęcona została Sąowej kontroli konstytucyjności prawa w Europie i w Stanach Zjednoczonych Ameryki Północnej. W jej trakcie zostały przedstawione modele sądownictwa konstytucyjnego wybranych państw europejskich oraz model amerykański. I właśnie od ukazania genezy i istoty modelu sądownictwa konstytucyjnego w USA w referacie dr Doroty Lis-Staranowicz (Uniwersytet Warmińsko-Mazurski) Model kontroli konstytucyjności prawa w Stanach Zjednoczonych Ameryki Pólnocnej rozpoczęła się sesja pierwsza. Zdaniem prelegentki podstaw dla kontroli konstytucyjności prawa w Stanach Zjednoczonych poszukiwać należy w zasadzie supremacji konstytucji oraz zasadzie wykładni konstytucji. Referentka wskazała cechy amerykańskiego modelu, którymi są: zdekoncentrowany charakter - każdy sąd amerykański może orzekać 
o zgodności z konstytucją, uniwersalność - każdy akt normatywny może być poddany kontroli, konkretność - kontrola ma charakter konkretny oraz względność kontroli, wiążąca się z faktem, iż orzeczenia o konstytucyjności wiążą jedynie w konkretnej sprawie, a powszechny charakter mają jedynie orzeczenia Sądy Najwyższego.

Kolejny referat, zatytułowany Sądowa kontrola konstytucyjności w Republice Litewskiej, przedstawiła dr Monika Giżyńska (Uniwersytet Warmińsko-Mazurski). Na wstępie swojego wystąpienia prelegentka podkreśliła odrębność rozwiązań litewskich, które odbiegają od modelowych rozwiązań kontroli konstytucyjności prawa przyjętych w państwach kontynentu europejskiego. Specyfika rozwiązań litewskich, zdaniem dr M. Giżyńskiej, przejawia się w: trybie wyboru sędziów (wybór przez Sejm, zwykłą większością głosów), odpowiedzialności sędziów Litewskiego Trybunału Konstytucyjnego za naruszenie konstytucji lub przysięgi oraz zakres uprawnień sądu konstytucyjnego w tzw. innych sprawach, w których sąd wydaje opinie niemające charakteru wiążącego.

Dr Anna Rytel-Warzocha (Uniwersytet Gdański) przedstawiła referat zatytułowany Kontrola konstytucyjności prawa w Szwecji. W Szwecji kontrola konstytucyjności prawa może mieć charakter kontroli prewencyjnej/ wstępnej - dokonywanej na etapie tworzenia prawa. Kontrola wstępna, która w sensie prawnym nie ma charakteru obligatoryjnego, faktycznie poddane są jej niemal wszystkie tworzone akty normatywne, prowadzona jest pod kątem zgodności z prawami fundamentalnymi i zawsze winna być prowadzona co do kwestii prawnych, a nie politycznych. Prowadzi ją Rada Prawa, uczestniczy w niej również Rikstag (przewodniczący Rikstagu i Komisja Konstytucyjna Rikstagu). Drugą formą kontroli jest w Szwecji kontrola następcza, mająca cechy systemu zdecentralizowanego.

Model niemieckiej i austriackiej kontroli konstytucyjności prawa przedstawił dr Szymon Pawłowski (Uniwersytet Kardynała Stefana Wyszyńskiego, Kancelaria Sejmu). Prelegent skupił się na charakterystycznych rozwiązaniach niemieckich i austriackich, koncentrując swoją wypowiedź na przedstawieniu konkretnych przypadków, w których udział brały Federalny Trybunał Konstytucyjny oraz Sąd Konstytucyjny Austrii.

Referat dr Katarzyny Kubuj (Instytut Nauk Prawnych Polskiej Akademii Nauk, Kancelaria Sejmu) zamykał część obrad poświęconą zagranicznym rozwiązaniom i dotyczył Kontroli konstytucyjności prawa we Francji. 
Prelegentka przedstawiła genezę kontroli konstytucyjności prawa we Francji, konkludując, iż dla przyjęcia instytucjonalnego kształtu kontroli zasadnicze znaczenie miały tendencje zmierzające do zabezpieczenia rządu przed ingerencją parlamentu w proces tworzenia prawa. Na przestrzeni lat zakres kompetencji Rady Konstytucyjnej ulegał jednak modyfikacjom, z których największą zmianę przyniosła nowelizacja Konstytucji V Republiki wprowadzona w 2008 r. Zakres właściwości Rady Konstytucyjnej został rozszerzony i, obok kompetencji dokonywania kontroli prewencyjnej, Rada uzyskała możliwość dokonywania kontroli następczej o konkretnym charakterze. Autorka zwróciła również uwagę na ciekawe rozwiązanie, obligujące Radę Konstytucyjną do rozpatrywania spraw w ramach kontroli prewencyjnej w ciągu 1 miesiąca, a w ramach kontroli następczej w ciągu 3 miesięcy.

Drugiej sesji, poświęconej Sądowej kontroli konstytucyjności w Polsce, przewodniczył dr Adam Zienkiewicz (Uniwersytet Warmińsko-Mazurski). Jako pierwszy w tej części seminarium referat przedstawił dr Stanisław Bułajewski (Uniwersytet Warmińsko-Mazurski). Tematem swojego wystąpienia uczynił Kontrolę konstytucyjności prawa miejscowego. Dr S. Bułajewski rozpoczął od konkluzji, iż poruszany przezeń temat jest kontrowersyjny i budzi szereg wątpliwości wśród przedstawicieli nauki prawa, a w zakresie dopuszczalności dokonywania kontroli konstytucyjności nie zostało wypracowane jednolite stanowisko doktryny. Przedstawiając argumenty za i przeciw objęciu kontrolą Trybunału Konstytucyjnego aktów prawa miejscowego, prelegent przychylił się do stanowiska części przedstawicieli nauki, według których Trybunał jest właściwy w sprawach kontroli konstytucyjności aktów prawa miejscowego, a dopuszczalną jej formą winna być instytucja skargi konstytucyjnej.

Dr Marcin Dąbrowski (Uniwersytet Warmińsko-Mazurski) w swoim wystąpieniu podjął próbę wskazania i omówienia Funkcji Trybunału Konstytucyjnego. Punktem wyjścia stało się zdefiniowanie pojęcia „funkcji” i odniesienia funkcji TK do funkcji państwa i prawa. Następnie autor wymienił syntetycznie i scharakteryzował funkcje - ochronną, która nie ogranicza się jedynie do ochrony systemu prawa, ale równie istotną jej rolą jest ochrona praw jednostki, stabilizacyjną - zmierzającą do utrwalenia i umocnienia ładu prawnego, uznanego za optymalny z punktu widzenia funkcjonowania państwa, a także funkcję sygnalizacyjną i interpretacyjną. 
Jako ostatnia głos zabrała dr Marzena Laskowska (Instytut Nauk Prawnych Polskiej Akademii Nauk, Kancelaria Sejmu), wygłaszając referat Polski Trybunał Konstytucyjny - postulaty zmian. Referentka skupiła się na przedstawieniu postulatów zmian, jakie znalazły swój wyraz w złożonych projektach ustaw nowelizujących ustawę o Trybunale Konstytucyjnym i projekcie ustawy zmieniającej konstytucję, a dotyczących sposobu wyboru sędziów Trybunału Konstytucyjnego oraz poddania kognicji Trybunału Konstytucyjnego prawa pochodnego Unii Europejskiej. Autorka przedstawiła również postulaty przedstawiane przez przedstawicieli nauki prawa dotyczące m.in. wyboru sędziów i ich kadencyjności, obsadzania funkcji stanowiska Prezesa i wiceprezesa Trybunału Konstytucyjnego, zreformowanie modelu kontroli konstytucyjności (poddanie kognicji także aktów stosowania prawa, wzmocnienie roli TK w sprawach indywidualnych), zmiany przepisów proceduralnych (objęcie wstępną kontrolą pytań prawnych, przedstawienie wstępnego sprawozdania, zredukowanie przebiegu rozpraw), zmian w zakresie kontroli prewencyjnej (związanie TK terminem rozstrzygnięcia) oraz kontroli abstrakcyjnej, a także wykonywania orzeczeń Trybunału Konstytucyjnego.

Po przedstawieniu referatów nastąpiła ożywiona dyskusja, w której odniesiono się do praktycznej strony działalności sądów konstytucyjnych i problemów wynikających z kontroli konstytucyjności prawa, relacji sądów konstytucyjnych i innych organów władzy sądowniczej.

$\mathrm{Na}$ zakończenie seminarium głos zabrała dr Joanna Juchniewicz (Uniwersytet Warmińsko-Mazurski), która w imieniu organizatorów podziękowała prelegentom za niezwykle interesujące, o wysokim poziomie merytorycznym wystąpienia, które niewątpliwie mogą stanowić asumpt do dalszych dyskusji nad modelami sądowej kontroli konstytucyjności prawa i zmian polskiego modelu kontroli konstytucyjności prawa. Wyraziła również nadzieję, iż seminarium olsztyńskie zapoczątkuje serię spotkań poświęconych tematyce sądownictwa konstytucyjnego organizowanych przez inne ośrodki akademickie w Polsce.

Joanna Juchniewicz (Uniwersytet Warmińsko-Mazurski w Olsztynie) 